\title{
Contextualizando o Sistema Únieo de Saúde e o processo comunicativo
}

\author{
Contextualizing the Unified Health System \\ and the communication process
}

\author{
Antônio Fernando Silva Xavier Júnior \\ Mestre em Nutrição - Universidade Federal de Alagoas \\ Professor da Faculdade Integrada Tiradentes (FITS)
}

\begin{abstract}
$\mathrm{O}$ mundo vem sofrendo intensas transformações. Essas mudanças passaram a colocar o profissional de saúde diante de um tênue discernimento entre o que poderia ser considerado freqüente e/ou não freqüente, questionamento normalmente praticado dentro de um plano cartesiano.
\end{abstract}

Acredita-se que na prática clínica, "entende-se" e "aplica-se" algumas vezes o conceito de saúde de maneira inapropriada. Saliento que este "entendimento" pode ser claramente identificado na hermenêutica do discurso de muitos profissionais, que outrora deveriam ser denominados de "profissionais de doença".

Esse entendimento não se coloca como errado, mas sim como inadequado às necessidades de saúde de grande parcela da população brasileira. Isto porque, baseia-se em um modelo flexneriano, que reflete uma visão biomédica, centrada na doença e não no sujeito enquanto "ser" e "agente social". O ser humano necessita ser atendido em suas condições mínimas de existência: educação, saúde, lazer, trabalho, moradia, transporte e etc., aspectos estes que o colocariam diante do conceito de viver com "qualidade".

O entendimento dos Determinantes Sociais de Saúde (DSS) conduz o profissional à reflexões básicas sobre os entraves enfrentados na prática clínica. Isso possibilitaria entender o que "pode" ou "deve" ser feito para melhoria da qualidade de vida dos usuários dos serviços de saúde.

A atenção primaria à saúde (APS) a mais de tinta anos tem se mostrado como um direcionador que deve embasar toda reformulação de modelos de atenção à saúde. No entanto, para que um modelo baseado em APS possa cumprir os objetivos, princípios e valores que se propôs, deve o mesmo contar com a adesão de todos os atores que preechem esse cenário: gestores, profissionais e usuários.

A Fonoaudiologia é uma ciência que emergiu na década de 80, época do surgimento do SUS, no entanto ainda enfrenta desafios frente ao alinhamento das necessidades impostas pelo sistema de saúde no contexto da realidade brasileira. Nesse texto, queremos situar o leitor frente às raízes históricas que influenciam as ações profissionais.

A terapia voltada aos "distúrbios da comunicação" sempre forneceu um direcionamento quanto às questões de "aperfeiçoamento profissional" no âmbito da comunicação. Mesmo quando inserida em outro contexto, educação, a atuação desses profissionais sempre esteve pautada na identificação de alterações de aquisição e/ou desenvolvimento da linguagem oral e escrita.

Atualmente, o profissional Fonoaudiólogo vem se inserindo cada vez mais em espaços de diálogo e gestão do SUS o que favorece o empoderamento enquanto ator 
social. Promover a saúde da comunicação vem se intensificando e deve compor cada vez mais a fala desses profissionais inseridos na rede de serviços de saúde.

O Núcleo de Apoio ao Saúde da Família - NASF, coloca-se como mais um campo de atuação para o Fonoaudiólogo, que deve construir ações intersetoriais e transdisciplinares voltadas a promoção de saúde comunitária no contexto que está inserido enquanto equipe (núcleo).

O diálogo social dessa forma, torna-se uma condição sine qua non, para coesão e coerência das ações proposta. Acredita-se que o Fonoaudiólogo, um profissional voltado a comunicação humana, projeta-se como um importante agente facilitador que pode favorecer e acompanhar o estabelecimento de um diálogo saudável eficaz no processo de construção de um SUS comunicativo e participativo. 